\author{
ツバメトコジラミによるヒト刺咬例 \\ 小松謙之*,1) 仲村 昇 ${ }^{2)}$ 山内健生 ${ }^{3)}$ \\ 1) 株式会社シー・アイ・シー・研究開発部（（１10-0014 東京都台東区北上野1-10-14） \\ 2) (財)山階鳥類研究所保全研究室／鳥類標識センター（テ270-1145 千葉県我孫子市高野山115） \\ 3) 兵庫県立大学自然・環境科学研究所 /兵庫県立人と自然の博物館 \\ （† 669-1546 兵庫県三田市弥生が丘 6丁目）
}

（受領：2016年6月2日；登載決定：2016年9月5日）

\title{
The cases of human infestation by the swallow bug Oeciacus hirundinis (Hemiptera: Cimicidae)
}

\author{
Noriyuki Komatsu*, ${ }^{*}$, Noboru Nakamura ${ }^{2)}$ and Takeo YAmaUCHI ${ }^{3)}$ \\ *Corresponding author: komatsu@cic-net.co.jp \\ 1) Civil International Corporation, 1-10-14 Kitaueno, Taito, Tokyo 110-0014, Japan \\ 2) Yamashina Institute for Ornithology, Division of Avian Conservation/Bird Migration Research Center, \\ 115 Konoyama, Abiko, Chiba 270-1145, Japan \\ 3) Institute of Natural and Environmental Sciences, University of Hyogo/Museum of Nature and Human Activities, \\ Hyogo, Yayoigaoka 6, Sanda, Hyogo 669-1546, Japan
}

(Received: 2 June 2016; Accepted: 5 September 2016)

\begin{abstract}
Human infestation of the swallow bug Oeciacus hirundinis (Hemiptera: Cimicidae) was confirmed in an apartment complex in the suburbs of Tokyo. Source of the bugs were nests of house martin Delichon dasypus attached to the outer wall. Swallow bugs were successfully eradicated from the room by applying heat and pesticide treatment for bedbugs. Bugs could be kept under captivity by feeding fetal mouse twice a month. We experimentally confirmed infestation by $O$. hirundinis. This report is the first confirmed human infestation and eradication case of the swallow bug in Japan. Since house martins are a common migratory bird in Japan, potential cases of human infestation may not be rare. In the future, it will be necessary to investigate bedbugs and their prevention, for preventing recurrence and identifying the kind and the nest building of the outside bird.
\end{abstract}

Key words: swallow bug, Oeciacus hirundinis, human infestation, control, Japan

\section{はじめに}

トコジラミ科は, 吸血性のカメムシ目昆虫で, 世界で 約90種が記録されている (Quetglas et al., 2012). 日本で は, トコジラミCimex lectularius Linnaeus, ネッタイトコジ ラミC. hemipterus Fabricius, コウモリトコジラミC. japonicas Usinger, およびツバメトコジラミOeciacus hirundinis (Lamarck) の4種が報告されている（安永，2001; 市川， 2009a, 2009b). トコジラミとネッタイトコジラミは家屋内に 生息し，ヒトの血を䬲とする重要な衛生害虫であり，全世界 で問題となっている (平尾, 2013)。一方，コウモリトコジ ラミとツバメトコジラミについても海外ではヒト刺咬例が知 られているが (Cranshaw et al., 1997; Trilar et al., 1997; Criado et al., 2011)，日本では報告されていない，本論文では，ツバメ トコジラミによる日本初のヒト刺咬被害と本種の防除事例の 概要を報告する.

\section{背景と経過}

2015年7月初旬, 東京都内にある鉄骨造の単身者用高層集 合住宅 14 階の入居者より, 株式会社シー・アイ・シー多摩 営業所の所員がトコジラミ類による被害と防除の相談を受け
た. 被害内容は, 吸血による痒みと, 徘䧃する虫への不快感 であった，後日，室内を調査したところ，ベッドの隙間や カーテンのひだ部分などに生息しているトコジラミ類を確認 した。防除は 1 週間の間隔をあけて 2 度実施した. 2 度とも に, ベッド周りのマットレスやヘッドボードなど, 肌が触れ る家具類を，業務用スチームクリーナー（製品名：DE 4002 プラス, ケルヒャージャパン株式会社製）により加熱殺虫を 行い, 家具裏・壁のクラック・室内コーナー等の人が触れに くい場所には, 有機リン系のマイクロカプセル剂（製品名: サフロチン ${ }^{\circledR} \mathrm{MC}$ ，日本化薬株式会社製）の 40 倍希釈液を約 $1 \mathrm{~L}$ 散布した. 2 度目の防除作業の 1 週間後に訪問し, トコジ ラミ類の被害や目撃がなくなったことを確認したため作業を 完了した.

作業完了の当日, ベランダが糞により污損する事を嫌った 入居者の依頼により, その部屋のベランダに造られたイワッ バメDelichon dasypus（Bonaparte）の巣を撤去した. その際, 巣内および撤去後の巣の跡等から複数のトコジラミ類が採集 されたことから, 詳細な調査と同定を行った (Fig. 1). 入居 者からの情報によると, イワツバメの営巣は数年前より行わ れていたが, 営巣開始時期は不明であった。 


\section{材料と方法}

現場には，イワッバメの完成した巣が 2 個と制作途中の巣 が1個あった. これらの内, 撤去後に原形をとどめていた巣 材の中から, トコジラミ類の付着が見られた一部分を持ち 帰った。イワッバメの巣材を少量ずつプラスチックトレー （322 mm $\times 234 \mathrm{~mm} \times 49 \mathrm{~mm}$, 株式会社大創産業製）に移しな がら目視にて虫体を採集した。死亡していた個体は，エタ ノール $70 \%$ 液を入れた容器に浸漬保管し, 生きた個体はポリ

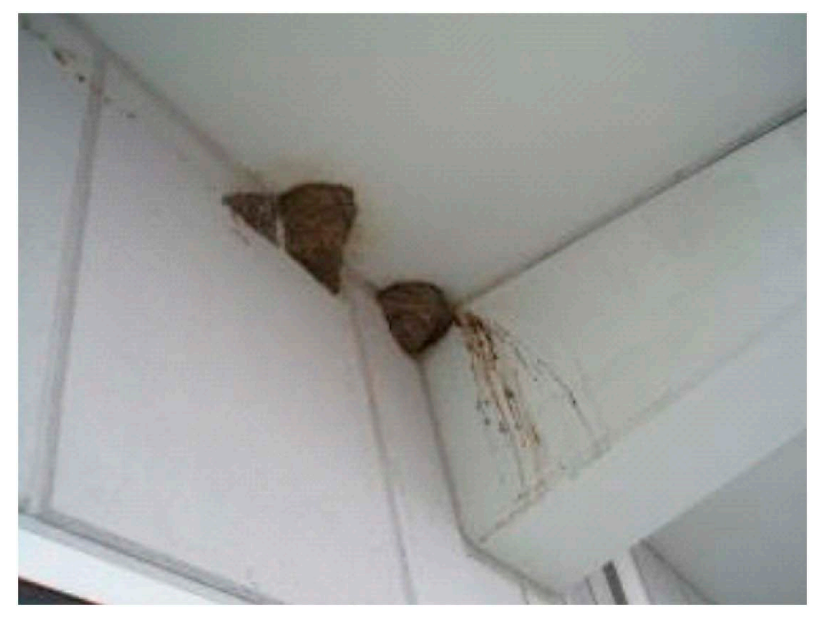

Fig. 1. Nests of the house martin Delichon urbica.
プロピレンの蓋付容器（ $160 \mathrm{~mm} \times 115 \mathrm{~mm} \times 95 \mathrm{~mm}$ ；株式会社 エンテック製）に入れて飼育した。

被害のあった室内からは，巣を採集した約 2 週間後，室内 の家具隙間に付着していた死亡している虫体をピンセットを 用いて回収した。

検体を水酸化カリウム $10 \%$ 液に約 24 時間浸漬し, ネオ・ シガラール液（株式会社志賀昆虫普及社製）にてプレパラー ト標本を作製した後, Usinger（1966）にしたがい同定した.

ツバメトコジラミが実際にヒトから吸血する様子を観察す るため，2015年 10月 21 日午前 10:00頃より吸血実験を実施 した. 供試虫として, 巣材から採集した後に生後 1 週間以内 のマウスを月に 2 回程度与えて飼育した雄成虫 1 個体を使用 した，被験者は，著者の一人であり，過去にトコジラミに 2 回, ネッタイトコジラミに 2 回吸血された経験を持つ 53 歳 の男性である。

腹部が扁平な個体を選定し，ピンセットにて左手の甲に配 置し, 吸血開始から終了までの時間と様子を観察した。

\section{結果}

研究室へ持ち帰つた巣材の総重量は $383.5 \mathrm{~g}$ で, 巣内より生 体死体合わせて 46 個体（雄成虫 12 個体，雌成虫 11 個体，幼 虫23個体）のトコジラミ類が回収された.

被害のあった室内からは, 4 個体（雌成虫 1 個体, 幼虫3 個体）のトコジラミ類死虫が回収された.

イワツバメの巣内および室内から採集されたすべての成虫

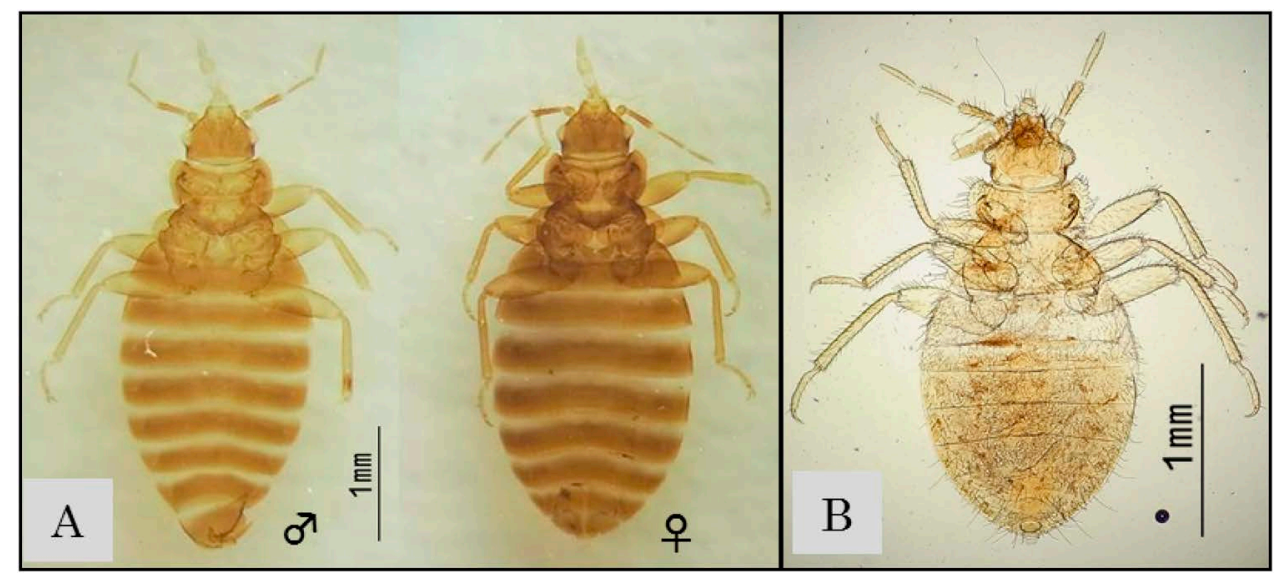

Fig. 2. Cimicidae collected from a nest of the house martin Delichon urbica. A: Adult male and female of Oeciacus hirundinis. B: Nymph of Cimicidae gen. sp.

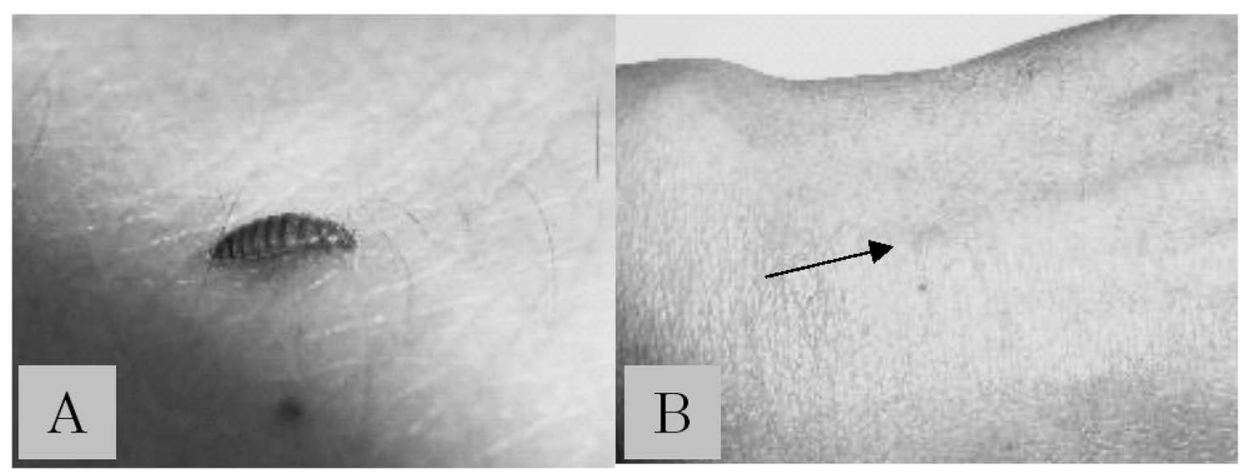

Fig. 3. A: The swallow bug Oeciacus hirundinis on the left hand during blood-sucking. B: An eruption caused by the swallow bug bite on the left hand. 
個体は, 雌雄ともに体長 $3.7 \mathrm{~mm}$ 内外で, 触角第 2 節の距離は 複眼間の $2 / 3$ かそれよりも短く, 前胸背板の幅は頭幅の 1.5 倍 以内であることにより, Oeciacus属と同定された。同属のO vicarius Horvath とは, 前胸背板の幅が $1 \mathrm{~mm}$ を超えることは なく，通常 0.83-0.9 mmであることにより識別された。 さら に，頭幅が $0.65 \mathrm{~mm}$ 内外であることからツバメトコジラミと 同定した（Fig. 2A）。幼虫に関しては，正確な同定はできな かったが，いずれの場所から得られた個体も，前胸背板の周 辺部には扁平部がなく, トコジラミの幼虫とは異なっていた (Fig. 2B).

吸血実験では，供試虫を被験者の手の甲にピンセットにて 静かに放飼すると，その場で口吻を伸ばし吸血を開始した (Fig. 3A). 吸血時間は，4分 23 秒であった。吸血途中，供試 虫は 1 回刺し場所を変更した. 被験者には, 吸血開始後しば らくして弱い痒みが生じ, この痒みが吸血終了まで持続し た. 吸血箇所には, 吸血後1分程度で淡い赤斑が発生した (Fig. 3B)．痒みは翌日には感じなくなったが，赤斑は 10 日後 まで残った。

\section{考察}

本調査では，室内とイワツバメの巣内から採集されたすべ ての成虫個体がツバメトコジラミであった。 したがって, ベ ランダに営巣されたイワツバメの巣に由来するツバメトコジ ラミが室内へ侵入し，ヒト刺咬が発生していた可能性が高い と考えられる. 今回の事例は, 室内のトコジラミ防除と, イ ワツバメの巣の撤去が同時期に行なわれたために判明した が, 室内の作業のみであった場合には, 通常のトコジラミ防 除とみなされていた可能性が高い。このことから，過去にも 今回と同様の事例が存在した可能性は高いと考えられる. 今 後, トコジラミの調査および防除の際には, 種の同定はもと より, 外周の鳥の営巣なども調査することが再発の防止に必 要であると考えられる.

ツバメトコジラミはヒトを刺咬しうる衛生害虫である (Cranshaw et al., 1997; Trilar et al., 1997; Criado et al., 2011) が, 本種の防除方法はこれまで知られていなかった．今回の事例 では，トコジラミ用の加熱殺虫と薬剤散布によりツバメトコ ジラミの防除に成功した. したがって, ツバメトコジラミ も，トコジラミに準じた方法で防除が可能であると考えられ た.

ツバメトコジラミは，イワツバメ以外にも19種の野鳥 の巣から記録されている (Trilar et al., 1997). それらの 内, 以下の6種は日本国内にも生息する：コシアカツバメ Hirundo daurica Linnaeus・ハシグロヒタキOenanthe oenanthe (Linnaeus)・ホシムクドリSturnus vulgaris (Linnaeus)・ア カゲラDendrocopos major (Linnaeus)・コルリLuscinia cyane (Pallas)・ツメナガセキレイ Motacilla flava Linnaeus. したがっ て，イワツバメ以外の鳥類が人家周りに営巣した場合にも, 本報告同様にツバメトコジラミによるヒト刺咬被害が発生す る可能性が考えられる.

本報告では，日本で初めて確認されたツバメトコジラミに よるヒト刺咬被害について述べた。 ツバメトコジラミによる ヒトへの吸血実験では，本種はヒトと接触後短時間で吸血行
動に移り，場所を移動することなく飽血するまで吸血してお り, ヒトに対して忌避行動はみられなかった。 また, 飼育状 態にて，マウスを供したところ，ヒトと同様に吸血行動が観 察され, 吸血可能な動物が鳥類以外にも複数あることが判明 した.

\section{まと め}

東京都内にある鉄骨造の高層集合住宅 14 階の居室内で, イワツバメの巣に由来したツバメトコジラミによる被害が発 生した. そこで, この居室にて, トコジラミ用の加熱殺虫と 薬剤散布を実施したところ，ツバメトコジラミの防除に成功 した. ツバメトコジラミは, 生後 1 週間以内のマウスを月に 2 回程度与えることにより飼育可能であった. 実験的にヒト からの吸血を確認した. 本報告は, ツバメトコジラミによる 日本初のヒト刺咬記録と本種の防除事例である。イワッバメ は日本国内に普通に生息する渡り鳥であることから，ツバメ トコジラミによる潜在的なヒト刺咬被害は少なくないかもし れない. 今後, トコジラミの調査および防除の際には, 種の 同定はもとより，外周の鳥の営巣なども調査することが再発 の防止に必要であると考えられる.

\section{謝 辞}

本文をまとめるにあたり，トコジラミ防除の情報およびイ ワッバメの巣を提供いただいた(株)シー・アイ・シー井上 修氏に深謝する。

\section{文献}

Cranshaw, W. S., Camper, M. and Peairs, F. 1997. Bat bugs, bed bugs and relatives. Colorado State University Extension. Fact Sheet, 5: 574.

Criado, P. R., Junior, W. B., Criado, R. F. J., Silva, R. V. and Vasconcellos, C. 2011. Bedbugs (Cimicidae infestation): the worldwide renaissance of an old partner of human kind. Braz. J. Infect. Dis., 15: 74-80.

平尾素一. 2013. 第3 章, 海外の現状. トコジラミ読本（ト コジラミ研究会監修), pp. 24-37. 日本環境衛生センター, 神奈川.

市川顕彦．2009a. ツバメトコジラミOeciacus hirundinis（半 翅目:トコジラミ科) の記録について その1. かめむし ニュース, 42:2-7.

市川顕彦。2009b.ツバメトコジラミOeciacus hirundinis（半 翅目：トコジラミ科) の記録について その2. かめむし ニュース, $43: 2-5$.

Quetglas, J., Balvin, O., Lucan, R. K. and Benda, P. 2012. First records of the bat bug Cacodmus vicinus (Heteroptera: Cimicidae) from Europe and further data on its distribution. Vespertilio, 16: 243-248.

Trilar, T., Gogala, A. and Gogala, M. 1997. Distribution of the swallow bug (Oeciacus hirundinis) in Slovenia, with an unusual finding in a fat dormouse (Myoxus glis) nest. Acta Entomol. Slov., 5: $45-50$.

Usinger, R. L. 1966. Monograph of Cimicidae (HemipteraHeteroptera). 585 pp., The Thomas Say Foundation, Vol. VII, Washington.

安永智秀. 2001. トコジラミ科。日本原色カメムシ図鑑第2 巻（安永智秀・高井幹夫・川澤哲夫編）, pp. 304-305. 全国 農村教育協会，東京。 